Working Paper No.1995/8

\title{
RECASTING COMMON SECURITY
}

\author{
Andy Butfoy
}

National Library of Australia

Cataloguing-in-Publication Entry

Butfoy, Andrew, 1958-

Recasting common security.

ISBN 0731521889.

1. Security, International. 2. International cooperation.

I. Australian National University. Department of International

Relations. II. Title. (Series: Working paper (Australian National

University. Dept. of International Relations); 1995/8.)

327.172

(C) A. Butfoy 


\section{DEPARTMENT OF INTERNATIONAL RELATIONS \\ WORKING PAPERS}

The Department's Working Paper series seeks to provide readers with access to current research on international relations. Reflecting the wide range of interest in the Department, it will include topics on global international politics and the international political economy, the Asian-Pacific region and issues of concern to Australian foreign policy.

Publication as a 'Working Paper' does not preclude subsequent publication in scholarly journals or books, indeed it may facilitate publication by providing feedback from readers to authors.

Unless otherwise stated, publications of the Department of International Relations are presented without endorsement as contributions to the public record and debate. Authors are responsible for their own analysis and conclusions.

Department of International Relations Research School of Pacific and Asian Studies Australian National University Canberra ACT Australia 


\begin{abstract}
The recent debate on new approaches to security has been marked by a mixture of platitudinous observations and an ad hoc search for policy relevance. This has lead to: (a) shallow theory and (b) a drift away from the radicalism implied in some early notions of 'common' security; the movement has tended to be towards relatively conservative thinking on 'cooperative' security. As a result of this, the debate has not been particularly profound. Nevertheless, it is possible to breath new life into the issue.
\end{abstract}





\title{
RECASTING COMMON SECURITY
}

\author{
Andy Butfoy*
}

\section{Introduction}

How should we enhance the prospects for international peace and security? What sort of ideas and policy guidelines are most likely to lead to a less war-prone world? What is the most sensible way of achieving both a safer and a less militarised international system? More especially, how should strategic planning be reformed to help bring about these changes?

One answer is to foster the development of common security. The notion of common security can be traced back to the early 1980s when it was offered as an escape route from the Cold War. The idea stressed non-competitive approaches to security, steps towards radical levels of disarmament, the need for a much stronger United Nations (UN), and Third World development. An important motivating force for this sort of thinking was the desire to break away from established mind-sets and show how the security of the world's population could be enhanced by the creation of a novel conceptual framework. At the time, though, this package of ideas was dismissed by most policy-makers and many academics as being confused, platitudinous and utopian.

However, during the late 1980s it appeared that Soviet leader Mikhail Gorbachev was embracing much of the logic and many of the policy implications of this 'alternative' approach to international security. Nowhere was this more apparent than in the dramatic progress made in arms control. It seemed that, under the Soviet label of 'New Thinking', aspects of the common security agenda could become mainstream. Following the end of the Cold War the scope for adopting common security appeared to broaden even further. A primary reason for this was the hope that a new concept of security could add direction to the reform of strategic planning which was deemed so necessary following the end of Superpower confrontation. A pervasive theme here has been the perceived opportunity, and need, to build on the notion of international interdependence. In order to put a contemporary, 'post-Cold War' stamp on the debate, this old idea was adapted to the circumstances (and intellectual mood) of the 1990s; it has been made more 'relevant'

\footnotetext{
The research for this paper was conducted while on study leave in the Department of International Relations, ANU, during March and April 1995. I am grateful to the following people for their remarks on an early draft of this chapter: Gavin Mount, Chris Reus-Smit, and Jim Richardson.
} 
and has been re-presented as cooperative security. ${ }^{1}$ By the mid-1990s cooperative security appeared to be orthodox wisdom in many, perhaps most, capital cities. Thus the overwhelming emphasis in official statements on security matters often tended to stress cooperative approaches to defence planning, arms control, nonmilitary dimensions of security, interdependence and multilateralism. Common security (or at least a version of it), it seemed, had 'arrived'.

The move to the mainstream did, however, have a significant casualty: the more radical ideas associated with some early notions of common security (such as de-nuclearisation, and a shift of resources to the Third World) were quietly put to one side. This shift towards a relatively conservative understanding of common security was reflected in officially endorsed Western notions of the new security agenda.

There is no authoritative definition of common security; and there is certainly no rigorous theory of the concept. Rather than being a theory, common security is a set of general perspectives. While it is true that these perspectives imply particular theoretical positions, there has been very little interest, within international relations, in exposing or refining what these positions are. One reason for this is simple enough: most attempts to articulate the meaning of common security have been tied to the exigencies of the moment (the risk of nuclear war in the early 1980 s, ending the Cold War in the late 1980s, stabilising the post-Cold War world order in the early and mid-1990s) rather than to the pursuit of scholarship. This

1 The literature on common and cooperative security is often vague on the precise relationship between the two terms. Sometimes they are treated synonymously, at other times they are viewed as quite different; most of the time they are given extremely vague meanings which offer considerable latitude in interpretation. In this study common security is seen as a concept which, in principle, encompasses (among other things) the military concerns found in the debate on cooperative security. A convenient way of looking at the issue is to see cooperative security as a contemporary, relatively conservative, variant of common security. The relationship between these terms will be explored in more depth in the paper.

The recent wave of literature advocating common security is usually traced back to the 1982 publication of the Report of The Independent Commission on Disarmament and Security Issues, Common Security: A Blueprint for Survival (New York: Simon \& Schuster, 1982); this Report is hereafter referred to as the Palme Commission, after its chairman, Olof Palme. For a more contemporary overview of the definitional issue, especially as it impacts on the AsiaPacific region, see David Dewitt, 'Common, Comprehensive, and Cooperative Security', Pacific Review, 7:1 (1994), pp. 115. As Dewitt notes, some notions of cooperative security are 'broadly similar' to ideas of common security; further, he adds that, 'any attempt to differentiate between them runs the risk of drawing artificial boundaries' (p. 1). For a discussion of cooperative security in its European context, see Stuart Croft, 'Cooperative Security in Europe',

(London: Brassey's, 1993), pp. 101116. For a relatively conservative version of common security, see Stan Windass and Eric Grove, The Crucible of Peace: Common Security in Europe (London: Brassey's, 1988). 
has given the common security literature a rather ad hoc character. One way to add some sharpness to our understanding of the issue is to recall some of its history. Another way is to recast the conceptual and ethical foundations of the idea of common security. This paper attempts to do both.

\section{The early development of common security}

A convenient, and conventional, starting date for this debate is the early $1980 \mathrm{s.}^{2}$ This period stands out for two related reasons: a growing dissatisfaction, amongst some academics and others, with the prevalent school within the study of international relations (i.e., Realism); and the perceived need to move away from the dominant Cold War mind-set. A general theme in advocacy of the new approach was that international security had become interdependent; building on this insight, it was argued that, contrary to Realist and Cold War logics, security had to be achieved through cooperation rather than competition. Attempts by one state, or one alliance, to gain unilateral security at the expense of others were, it was claimed, short-sighted and dangerous. More particularly, it was argued that such policies merely fuelled the 'security dilemma' (this dilemma arises when defensive measures can be interpreted as offensive, thus producing defensive counterpreparations which also look offensive, and so on; each side becomes locked into arms racing even if both only want an adequate defence).

\section{The rejection of the Cold War mind-set}

During the dark days of the Cold War in the early and mid-1980s, there were calls for the 'Establishment' to recognise, and act upon, the emerging notion of common security. It was argued that the only real escape route from an allegedly impending nuclear Armageddon was to embrace this alternative approach to international politics.

One of the pivotal early documents on the subject was published in 1982: Common Security: A Blueprint for Survival, a report by the Independent Commission on Disarmament and Security Issues (usually referred to as the Palme Commission). ${ }^{3}$ The report carried the signs of being written by a committee,

For a sketch of the earlier antecedents of common security thinking, see Geoffrey Wiseman, Common Security and Non-Provocative Defence: Alternative Approaches to the Security Dilemma (Canberra: Peace Research Centre, ANU, 1989). For a less Eurocentric and more recent discussion, see Dewitt, 'Common, Comprehensive, and Cooperative Security'. Dewitt begins his paper with a discussion of the Japanese idea of comprehensive security which was developed in the 1970s; this idea stressed the multidimensional nature of Japanese security concerns (territorial defence, cooperation with the US, secure energy and food supplies, etc); the focus here is on national well-beingnet on reforming international relations. 
especially regarding an uneven mixture of radicalism and 'centrist' sentiment. Nevertheless, many of the arguments and themes which came to fill-out the early common security agenda were provided by peace research centres which took this report as a key reference point; the foremost of these being the Stockholm International Peace Research Institute (SIPRI). ${ }^{4}$

Much of the internal logic of the report was driven by the idea that arms racing was inherently wasteful, harmful to the prosects for development in the Third World and-above all else-dangerous. According to the Palme Commission, which in many ways reflected Centre-Left European opinion, ${ }^{5}$ there was a 'drift towards war', ${ }^{6}$ the world seemed to be 'marching towards the brink of a new abyss'. Following the logic of the report, it was argued that, 'the ultimate goal must be general and complete disarmament'. ${ }^{8}$ Piecemeal arms control was rejected unless it took place within a clear framework leading to radical levels of demilitarisation:

...nations must strive for objectives more ambitious than stability, the goal of the present system in which security is based on armaments. For stability based on armaments cannot be sustained indefinitely. There is always the danger that the fragile stability of an international system based on armaments will suddenly crumble, and that nuclear confrontation will take its place. A more effective way to ensure security is to create positive processes that can lead to peace and disarmament. It is essential to create an irreversible process, with a momentum such that all nations cooperate for their common survival. ${ }^{9}$

Within the general area of arms control, the Commission called for an emphasis on 'reducing those elements of...military postures which [are considered] 10 This, ideally, would be paralleled by the development of 'confidence and security building measures' (CSBMs), especially measures which would 'inhibit the use of military activity to exert political pressures, and those

See, for example, Emma Rothschild, 'Common Security', SIPRI Yearbook 1984 (London: Taylor \& Francis, 1984), pp. 583590.

$5 \quad$ As a general overview of the Palme Commission, this characterisation is valid, but it should not be pushed too far. Apart from Europeans, there were members from the Soviet Union, Africa, Asia, Mexico, Canada, and the US.

$6 \quad$ Palme Commission, p. xiii.

$7 \quad$ Palme Commission, p. 1.

8 Palme Commission, p. 177. This objective was, however, more-or-less rejected in some relatively conservative notions of common security. See Barry Buzan, 'Common Security as a Policy Option for Japan and Western Europe', in Radmila Nakarada and Jan Oberg, Surviving Together: The Olof Palme Lectures on Common Security 1988 (Hampshire: Dartmouth Publishing Company/Gower Publishing Group, 1989).

$9 \quad$ Palme Commission, p. 7.

$10 \quad$ Palme Commission, p. 146. 
which reduce the danger of surprise attack' (with the emphasis being placed on the latter). ${ }^{11}$

A fresh approach to security in 1982 seemed appropriate because the traditional arms control process was largely discredited; it consequently had a very limited constituency. The Right saw the exercise as a manifestation of 'going soft' on Moscow, a form of appeasement; the Centre was frustrated because the whole process seemed dead in the water; the Left saw arms control as a sham which was actually disguising (and in some cases rationalising) an arms build-up and diverting attention away from the goal of disarmament. In addition, the Peace Movement was gathering steam in Europe. The movement was being fuelled by the exchange of hostile, somewhat alarming, US-Soviet propaganda; it was also becoming increasingly sophisticated politically, as well as becoming more astute and articulate in its critiques of strategic planning. This factor provided an important part of the background to the ensuing debate.

A special area of concern was signs of increasing nuclearisation of relations between the North Atlantic Treaty Organisation (NATO) and the Soviet dominated Warsaw Pact. This development seemed to be underlined by the US deployment of ground launched cruise missiles (GLCM) and Pershing II missiles in Europe, together with loose talk from Washington about the feasibility of winning World War Three. ${ }^{12}$ Even on the conventional level it seemed to many observers that NATO was gearing-up for an enormously expensive arms race in order to equip the Alliance with a capability to launch military offensives deep into Eastern Europe. ${ }^{13}$ Although this revamping of conventional forces and military doctrine was rationalised by NATO in terms of its putative contribution to deterrence, it seemed to critics that it was actually pushing Europe towards, rather than away from, conflict.

$11 \quad$ Palme Commission, p. 117.

12 To get a sense of some of the signals coming out of the US at this time, see Robert Scheer, With Enough Shovels: Reagan, Bush and Nuclear War (New York: Random House, 1982). For a sample of some of the ideas on nuclear war that many critics saw as very alarming see: Colin Gray, 'Nuclear Strategy: The Case for a Theory of Victory', International Security, 4:1 (Summer 1979). Even many supporters of NATO and deterrence suspected that the West was too dependent on nuclear weapons; see, for example, John Steinbruner and Leon Sigal (eds), Alliance Security: NATO and the NoFirst-Use Question (Washington: The Brookings Institution, 1983). For an analysis of NATO's Cold War 'nuclear addiction', see David Schwartz, NATO's Nuclear Dilemmas (Washington: The Brookings Institution, 1983).

13 Such suspicions were fuelled by studies calling for enormously expensive 'deep-strike' conventional weapons programs; see, for example, the European Security Study (ESECS), Strengthening Conventional Deterrence in Europe (London: Macmillan, 1983). 
The development of common security was, then, to a considerable extent, a byproduct of the Cold War. ${ }^{14}$ Common security, it was argued, would provide Europe, and other regions, with an alternative to falling victim to a reckless Superpower competition. ${ }^{15}$ The need for alternative approaches to security was felt especially keenly in areas most vulnerable to a deterioration in Superpower relations (particularly West Germany and Scandinavia).

Most supporters of the new approach realised that general and complete disarmament was not a realistic short term goal. As a compromise they strongly advocated the adoption of 'alternative defence'. Alternative defence encompassed 'non-offensive defence' (NOD) and 'non-provocative defence' (NPD). These terms were frequently used interchangeably, although NPD has often been used somewhat more vaguely. ${ }^{16}$ In its 'pure' form, NOD was defined quite rigorously: as $a$ military posture which is structurally incapable of engaging in sustained strategic offensives. A key promise of NOD was effective territorial defence without compromising the security of neighbouring states. It was stated that the adoption of NOD would (a) lower the probability of war occurring, (b) reduce the risk and dangers of escalation in the event of war, (c) provide a more efficacious defence if war broke out, and (d) enhance the prospects for stable political relations across the East-West divide. ${ }^{17}$

This approach to defence was novel in that it was intended to increase simultaneously Western and Soviet security. More specifically, it was claimed that NOD would reduce Moscow's fears of NATO military capabilities. NOD, it was argued, would reassure the Soviet Union and thereby dampen the arms race. Nonoffensive defence seemed to fit perfectly into notions of common security; it

See, for example, Barry Buzan, 'Common Security, Non-Provocative Defence, and the Review of International Studies, 13 (1987), pp. 265279.

An additional advantage of following the logic of common security, it was asserted, would be a radical improvement in NorthSouth relations, especially the enhancement of development efforts in the Third World. This would occur, it was hoped, for two reasons: funds could be diverted from the arms race to development; and concerns for global well-being could supersede the obsession with strengthening deterrence. See, for example, the Palme Commission, especially chapter four.

16 See Andrew Butfoy, Critical Reflections on Non-Offensive Defence (Melbourne: Centre for International Relations, Monash University, Working Paper 14, 1995).

17 For surveys of the debate on non-offensive defence in Europe during the 1980 s, see J. Dean, 'Alternative Defence', and Horst Afheldt et al., 'A New European Defense'Special Edition of Bulletin of the Atomic Scientists, September 1988; Andrew Mack, 'The Strategy of Non-Provocative Defence: The European Debate', in Desmond Ball and Cathy Downes (eds), Security and Defence: Pacific and Global Perspectives (Sydney: Allen \& Unwin, 1990); and Stan Windass (ed.), Avoiding Nuclear War: Common Security as a Strategy for the Defence of the West (London: Brassy's, 1985). 
appeared to offer a way of side-stepping (or at least ameliorating) the security dilemma by developing relatively benign forms of military power.

But, before the logic of peace-through-reassurance could be made convincing, it was deemed necessary to demolish notions of peace-through-strength; this, in turn, was thought to require the rejection of Realist theories of international relations.

\section{The critique of Realist perspectives}

This is not the place to provide a full account or comprehensive evaluation of Realist theory. Nevertheless, some discussion of the subject is required because supporters of common security often use Realism as a foil or counter-point in efforts to set their ideas up as distinctly 'alternative'. 18

The Realist school of international relations represents a broad church; it covers a relatively wide spectrum of explanatory and normative opinions. ${ }^{19}$ Despite this pluralism, it is possible to offer a general description. Realism purports to portray the world 'as it is'-rather than as it should or could be. To a large extent Realist arguments were developed in response to the utopian 'Liberal Internationalism' (often seen as 'Idealism' or the 'World Society' perspective) which helped mark out Western international relations thought in the 1920s. Liberal Internationalism suggested that the path to a pacific world society would lie through disarmament, international law, international organisation, and the working out of an underlying harmony of interests. These ideals were dashed by the rise of fascism. Realism was, in part, an attempt to show how Liberal Internationalism was out of touch with the dominant forces of, and critical constraints within, the international system.

Realism tends to view international relations in terms of 'a balance of power'20 between sovereign states. These states pursue (what critics see as relatively narrow conceptions of) their individual national interests in an anarchic international system. These interests frequently run up against each other; this is the primary

18 For example, see Ken Booth (ed.), New Thinking About Strategy And International Security (London: Harper€ollins Academic, 1991), especially the Introduction and Conclusion.

19 Perhaps the biggest division within this school is between the 'classical' and the 'structural' Realists. In terms of explaining world politics, the former places greater emphasis on human nature and history; the later (usually termed Neo-Realism), stresses the anarchical structure of international relations. Two of the most prominent representations of these approaches are (for Neo-Realism) Kenneth Waltz, Theory of International Politics (Addison-Wesley, 1979) and (for classical Realism) E.H. Carr, The Twenty Years' Crisis, 1919-1939: An Introduction to the Study of International Relations (London: Macmillan, 1939).

20 The place of the balance of power in Realist thought is a complex one; it has frequently been used ambiguously and many Realists appear to have an ambivalent attitude towards it. 
cause of war. War (or at least the possibility of war) is seen as both inherent in, and almost a defining feature of, international relations. In the 'dog-eat-dog' world pictured by many Realists, states are compelled to look, first and foremost, to their own survival and position in the international balance of power. Acceptance of this logic encourages a view of security which is frequently equated with a quest for national power; this power is, itself, often seen in terms of military capabilities. Traditionally, the military forces which seem to carry most weight in the great scheme of things are those which give a government significant offensive capabilities. It is these capabilities which underline a state's will and power to pursue its own interests, if necessary at the expense of all other members of the international system. This focus on national interests leaves concerns with global issues out on the periphery. This, in turn, means that international law and international organisation work within very tight constraints and cannot be expected to change the substance of international relations.

According to its many critics, the Realist perspective is seriously flawed as both a description of the world (including its history) and as a guide to action. ${ }^{21} \mathrm{~A}$ particularly worrying aspect of Realism is that the mutual suspicions and arms racing which it rationalises could become self-fulfilling prophecies. It is feared that this sort of theory can all too easily become practice. ${ }^{22}$ (For example, it has been suggested that the Cold War was perpetuated by, among other things, the parroting of nuclear deterrent strategies dressed up as objective-Realist-analysis. ${ }^{23}$ What is needed, it is argued, is a conception of world politics which places more emphasis on the possibility of political and ethical evolution beyond the static, and ethically stunted, picture given by Realists.

Critics also argue that Realism is oblivious to profound developments which are changing the nature of international relations. Foremost of these developments are growing interdependence, evolving notions of international and global community, and challenges to state sovereignty. It is not just the rejection of the

21 For critiques of Realism, see, for example, the various chapters in Robert Keohane (ed.), Neorealism and its Critics (New York: Columbia University Press, 1986); Richard Ned Lebow, 'The Long Peace, the End of the Cold War, and the Failure of Realism', International Organization, 48:2 (Spring 1994), pp. 249277; and Alexander Wendt, 'Anarchy is What States Make of it: The Social Construction of Power Politics', International Organization, 46:2 (Spring 1992), pp. 391425.

22 See, for example, Michael MccGwire, 'Deterrence: the ProblemNot the Solution', International Affairs, 62:1 (Winter 1985/86), pp. 5570.

23 For a discussion on a related theme, see Andrew Butfoy, 'Rationalising the Bomb? Strategic Studies and the US Nuclear Umbrella', Australian Journal of Politics and History, 40:2 (1994), pp. $145 \pm 61$. 
structural givens of Realism (i.e., sovereign states living in an anarchic international system) that is relevant here. There is also the argument that, even within the structure outlined by Realism, political behaviour can mature in benign ways. Decades ago Karl Deutsch noted the development of 'pluralistic security communities': groups of sovereign states that, as far as relations among themselves are concerned, have rejected the idea that war is a sensible or acceptable extension of diplomacy. ${ }^{24}$ Examples here are Norway-Sweden, Canada-USA, much of the European Union, and New Zealand-Australia. It is said that the reason for the absence of war in such cases has nothing to do with deterrence or assessments of the balance of power.

Another argument made by critics is that some notions of Realism place far too much emphasis on the issue of 'relative gains' (or the attempt by states to enhance their position in the international league table). A better key to understanding state behaviour in some situations is the notion of 'absolute gains'. States, the argument goes, are not necessarily obsessed with their power relative to others; they are far more concerned with net gains. To the extent that this critique of Realism holds water, it has significant implications for evaluating the prospects for international cooperation (including the prospects for international organisations). It says that, in some circumstances, rational calculations of state interests point towards the acceptance of relative losses. ${ }^{25}$

Critics call for a conceptual antidote to Realism, a cure for the blindness supposedly produced by too close an attachment to the theory. ${ }^{26}$ The putative requirement here is for what Ken Booth calls 'consciousness raising'. ${ }^{27}$ Booth notes that: "The "reality" of the strategic world is closely bound up with our image of it'.28

'Karl Deutsch et al., Political Community and the North Atlantic Area (New York: Greenwood Press, 1957).

25 For an examination of the relationship between Realism and the issue of relative/ absolute gains, see, for example, Robert Keohane, 'Institutional Theory and the Realist Challenge after the Cold War', in David Baldwin (ed.), Neorealism and Neoliberalism: The Contemporary Debate (New York: Columbia University Press, 1993). As Keohane notes, both Realists and proponents of absolute gains base their argument on a picture of international relations which is driven by states calculating ways of maximising self-interest. The key difference is that the latter group, 'argues that where common interests exist, realism is too pessimistic about the prospects for cooperation and the role of institutions...' (p. 277). See Ken Booth, 'Steps Towards Stable Peace in Europe: A Theory and Practice of International Affairs, 66:1 (1990), pp. 1745.

Booth, 'Steps Towards Stable Peace in Europe', p. 33.

Booth, 'Steps Towards Stable Peace in Europe', p. 23. This observation, of course, works both ways: it suggests that consciousness raising on behalf of common security has a rolebut that its impact is constrained by competing thoughts (what Booth, on pp. 2022 , calls 'regressive mindsets'). 
Change the image, he is saying, and thereby go a long way towards changing the reality. For many people, the obvious way of moving towards a new reality was to advocate an expansive notion of common security.

\section{The broadening of ideas of security}

By the mid-1980s there was a relatively firm pattern emerging in parts of the international relations literature whereby security was defined in broader and broader terms. The Palme Commission, despite its focus on nuclear issues, signalled this development by targeting 'poverty, unemployment, inflation' and 'the threat of

${ }^{29}$ Each of these phenomena, it implied, could threaten the security of all. More particularly, it argued that economic development in the Third World should be seen as integral to any long-term scheme for global security. A major concern was 'growing economic and social disparities between North and South' which could lead to 'worldwide chaos and international conflict'. ${ }^{30}$ It continued:

Common security is not only a matter of freedom from military fear. Its objective is not only to avoid being killed in a nuclear apocalypse, or in a border dispute, or by a machine gun in one's own village. Its objective, in the end, is to live a better life: in common security and common prosperity. ${ }^{31}$

The placing of broad development issues in the Third World on to the common security agenda was a very frequent practice during the $1980 \mathrm{~s} .{ }^{32}$ This interest in development was frequently packaged together with concerns over the arms race. One statement on 'global problems and common security' called for the following:

a nuclear weapon-free world;

- the creation of a framework of international economic, technological, cultural, and humanitarian interaction and cooperation [by] which the use of nuclear weapons and other weapons of mass destruction becomes unthinkable;

- the full demilitarization of international relations;

- $\quad$ the closing of the prosperity gap between the North and the South; and

29 Palme Commission, p. 71.

$30 \quad$ Palme Commission, pp. 1112.

$31 \quad$ Palme Commission, p. 176.

32 See, for example, Kenneth Dadzie, 'Report on the Discussions in Working Group IV: Common Security and the Third World', in SIPRI, Policies for Common Security (London: Taylor and Francis, 1985) pp. 231235; Joseph Rotblat and Vitalii Goldanskii (eds), Global Problems and Common Security (Berlin: Pugwash-Springer-Verlag, 1989); and Joseph Rotblat and Laszlo Valki (eds), Coexistence, Cooperation, and Common Security (Basingstoke: Macmillan, 1988). 
- a transition to technologies of energy supply, agriculture, and industrial production that are both environmentally sustainable and resource-efficient. ${ }^{33}$

Some people argued that international security should be seen in radically comprehensive terms: as something which is all-embracing-covering, for example, environmental and social dimensions as well as traditional military and economic factors. According to this reasoning, a correct approach to the examination of national and international security would have to look at issues as diverse as ozone depletion, rising sea levels, deforestation, unemployment, violence in the home, inappropriate (war) toys for children and so-on. ${ }^{34}$ Broadening the range of issues covered in the discourse on international security implied, to some advocates, a need to reconstruct old mindsets. Booth has argued that: 'Learning common security involves creating organisations at all levels from the state down to towns, firms and educational bodies'. ${ }^{35}$

\section{An assessment of early notions of common security}

\section{Underlying assumptions}

In the early and mid-1980s common security usually meant suffusing the idea of strategic and economic interdependence with moral argument which pointed towards (a) the eventual achievement of general and complete disarmament, and (b) the universal acceptance of common interests in peace and development. As a stepping stone to this new world, and as a sign that the real world of policy choice was being faced up to, advocates suggested ways of de-emphasising both nuclear deterrence and offensive conventional military strategies; in addition there were strong calls for constraining the arms trade.

Many of these early approaches to common security appeared to reflect four assumptions. The first of these was that a historical process was at work which would (if only the Establishment allowed it) more-or-less inevitably move us towards an increasingly mature anarchy and, ultimately, a radically transformed international system. ${ }^{36}$ Within this setting, it was believed (and without much

Rotblat and Goldanskii (eds), Global Problems and Common Security, pp. 255256.

See Gary Smith and StJohn Kettle (eds), Threats Without Enemies: Rethinking Australia's Security (Leichhardt: Pluto Press, 1992); the point about the relevance of domestic violence and children's toys is made in the chapter by Di Bretherton, Towards a Secure Community'.

This assumption clearly does not underlay more conservative notions of 'new' approaches to security. See, for example, Janne E. Nolan (ed.), Global Engagement: Cooperation and Security in the 21st Century (Washington DC: The Brookings Institution, 1994), p. 5: 'Cooperative security is not a description of the inexorablity of 
critical reflection) that the international system would be increasingly definable in terms of learned cooperative behaviour and increasing convergence in international norms. Issues of identity, and the existence of diverse long-term political aspirations, were not seen as insurmountable barriers to the achievement of a radically new world order marked by political, cultural and economic accommodation, peace and sustainable development. This was echoed in a related point made by the Palme Commission when it implied that common prosperity could provide the basis for common security. ${ }^{37}$

Second, much of the security literature assumed that the so-called 'indivisibility of peace' was a self-evident fact. This notion is based on the assertion that a breakdown of the peace anywhere is a danger to the peace everywhere. Thus we get the following sort of comment by Werner Feld: '[thoughtful Europeans] recognise...that the security of every CSCE signatory is inseparable from the security of all other CSCE members'. ${ }^{38}$ In other words, it is being claimed by Feld (and others) that, for example, thoughtful Irish citizens would view threats to the security of fellow CSCE member Tajikistan as inseparable from the security of Ireland.

Third, it was often assumed that war is essentially caused by misperception and miscalculation. The suggestion was that no one in his or her right mind would deliberately choose to precipitate a war as a rational and morally acceptable instrument of policy. This issue of miscalculation is connected with the fourth assumption that needs to be mentioned here: that weapons and arms racing can cause war. The belief is that arms races can become autonomous phenomena and escape political control. These two interrelated beliefs helped to underpin the interest in CSBMs and eventual complete disarmament; they also helped to drive advocacy of NOD.

\section{A critique of the early ideas of common security}

The conceptual package represented by much of the early thinking on common security rests on a flawed understanding of how the world really works. Indeed, critics could well argue that many of the ideas that gained prominence during the 1980s bore more than a passing resemblance to the discredited Liberal Internationalism of the 1920 s and 1930s. Thus parts of the critiques of inter-war

a peaceful world system, a prediction about how the future will actually be formed, or a theory of international relations'.

37 Palme Commission, especially chapter four (e.g., p. 96); in addition see p. 130, 'Peace and prosperity are two sides of the same coin'. A similar point seems to be implied by Gareth Evans, see 'Cooperative Security and Intrastate Conflict', Foreign Policy, 96 (Fall 1994), p. 11.

38 Werner Feld, The Future of European Security and Defence Policy (Boulder: Lynne Rienner, 1993), p. 69. 
idealism could be wheeled out and employed against common security. For a start, the international system is obviously not a particularly harmonious or homogeneous political arena. 39 So, as frequently noted in the international relations literature, any scheme for world order reliant on a belief or hope that below the surface there is some kind of natural underlying convergence of interests and values which is underdeveloped and 'just waiting' to manifest itself is suspect. It is not sensible to assume, for example, that if only more people were educated about the nature and merits of common security the international system would become peaceful. 'Consciousness raising' can only get us so far.

The absence of universal acceptance of a particular 'ideal type' of world order is underlined by the frequent rejection, in practice, of the notion of the indivisibility of peace. There are, to go back to the example cited earlier, probably numerous thoughtful Irish men and women who would argue that it makes considerable sense to see their security as separable from that of fellow members of the CSCE such as Tajikistan. There is little to be gained, and some credibility to be lost, in pretending that the indivisibility of security is accepted by all. As argued later, this issue is linked to the lack of universal concern in the collective fate of humanity-a lack of concern which is one of the primary obstacles to, among other things, radical strategic reform.

This is linked to another problem. The implied universalisability of common security seemed to betray a naive belief that a global culture might be developing in ways which mirror some Western notions. The 'problem', of course, is that this global culture might not really exist and might never come into being. ${ }^{40}$ This has significant implications for any attempt to fill out a universally accepted meaning for 'the good life' (which in international relations largely amounts to security of one form or another). For one thing, war-and therefore preparation for war-acquires meaning from, indeed can be seen as a product of, culture. ${ }^{41}$ Yet most of the literature on common security appears to be muted on the issue. The hope appears to be that one day most of us will wake up and accept some kind of a liberal democratic version of Village Earth.

39 One only has to look at, for example, contemporary UStranian relations or PakistaniIndian relations to see this. Even here, though, one must be careful not to fall into the opposite trap and assume that these sorts of relationships are inevitably trapped in antagonism for all time.

40 See Anthony Smith, 'Towards a Global Culture?' in Mike Featherstone (ed.), Global Culture, Nationalism, Globalisation and Modernity (London: Sage, 1991). There is, however, considerable room for international dialogue along common security lines even in a fragmented World: see Richard Shapcott, 'Conversation and Coexistence: Gadamer and the Interpretation of International Society', Millennium, 23:1 (Spring 1994).

41 A point well made by John Keegan in A History of Warfare (London: Pimlico, 1993). 
But, for the time being at least, Village Earth is, in political terms, more of a slogan than a reality-especially in the realm of war and peace. Any serious proposal for enhancing security has to avoid the common and daft idea that because war is frequently dysfunctional and wicked it cannot happen. The alternative is to fall into traps which discredit the common security agenda. For example, Bjorn Moller, in a book published in 1992 (but presumably drafted before the break-up of Yugoslavia), was bold enough to state that 'salami' aggression—or, 'the conquest of a small piece of territory'-is so improbable that it 'does not merit serious attention [by defence planners], at least as far as Europe is concerned'. ${ }^{2}$ This sort of analysis will not do. The task is to identify (and then perhaps tame) some of the competitive and antagonistic aspects of international relations; to assume that these aspects can be wished away is asking for trouble.

Here it is worth underlining the fact that Realist notions reflect important aspects of the international context that many states find themselves in but which some advocates of common security only half-heartedly acknowledged. There is no world government; the potential for war remains embedded in the international system; independent statehood is much valued by many communities; sovereignty can have a positive value which should not (and perhaps cannot) be fully supplanted by the homogenising visions of international relations implied in some notions of common security; and, similarly, 'anarchy' at the international level also has some positive aspects, especially if it is seen as 'a decentralised form of political 43

Moreover, in some circumstances, the logic of absolute gains fails to grasp what happens in the world.44 The rational maximising of welfare does not define the nature of international politics. There will indeed be occasions when officials are very mindful of (perhaps even obsessive about) the relative position of their stateeven if this means serious costs are incurred and absolute gains are sacrificed. This may be especially so with military matters. For example, it is extraordinarily difficult to imagine Washington accepting military parity with (say) Japan, Mexico,

Bjørn Møller, Common Security and Nonoffensive Defense: A Neorealist Perspective (Boulder, CO: Lynne Rienner, 1992), p.179.

43 Barry Buzan, People, States and Fear: An Agenda for International Security Studies in the Post-Cold War Era (Hemel Hempstead: Harvester Wheatsheaf, 1991), p. 21. Buzan continues:

Anarchy can be seen fatalistically as a product of history...or the natural political expression of a...diverse population. It can also be seen as a preferred form of political order, representing values of ideological and cultural diversity, economic decentralisation and political independence and self-reliance.(p. 22).

44 For an argument which emphasises the continued importance of relative gains calculations, see Joseph Grieco, 'Understanding the Problem of International Cooperation: the Limits of Neoliberal Institutionalism and the Future of Realist Theory', in Baldwin (ed.), Neorealism and Neoliberalism, pp. 301338. 
Cuba, or Panama (or even the four in combination) whatever the absolute gains in US security might be.

In addition, the choice offered by some advocates of common security, between red-clawed Realism and a 'new' or 'alternative' vision of benign common endeavour, obfuscates much of the academic debate as well as most of the political practice which occurs in the space between these two extremes. (This issue is discussed in more depth below.)

Another problem with some efforts to advocate common security was the temptation, mentioned earlier, to prevent narrowness by bringing everything (such as the fate of tropical rain forests, and wife-bashing) into the debate. This stretching and pulling of the boundaries of the discourse on security has been both thought provoking and distracting. Thought provoking because issues like deforestation and domestic violence are clearly threats to the well-being of millions of people; distracting in the sense that these sorts of issues were rhetorically, rather than analytically, linked to issues of war prevention. Broadening the agenda has sometimes added to a blurring of analytical focus and a diminution of policy usefulness. In 1987 Buzan was moved to note that the term common security is used by a variety of writers with quite different purposes in mind, and is therefore in danger of degenerating into an empty phrase' ${ }^{45}$

\section{Common security co-opted? Towards cooperative security}

\section{Common security as conventional wisdom?}

Until at least the latter half of the 1980s the concept of common security was on the margins of official interest and concern. Common security was, in some important respects, the voice of protest and dissent. As outlined above, advocates of common security wanted to overturn orthodox wisdom, especially in its Cold War form.

The turning point in the move from protest to mainstream interest came as Soviet leader Mikhail Gorbachev appeared to endorse much of the rhetoric associated with common security. Gorbachev's pronouncements on 'New Thinking' stressed themes which were strikingly similar to many of the earlier ideas which came out of a variety of Western academic and peace movement sources. Economic, environmental and strategic interdependence were stressed; the standard polemics on deterrence and class war were pushed well into the background-and then removed entirely from Moscow's foreign policy vocabulary. ${ }^{46}$ The most tangible

45 See 'Common Security, Non-Provocative Defence, and the Future of Western Europe', p. 265.

46 See Mikhail Gorbachev, 'United Nations Address' (press release, Novosti Press Agency, December 1988). For a discussion of the context for the shift in Soviet policy, see 
49 Within a decade a version of collective security had been implemented with startling effect.

In the subsequent 'New World Order' proclaimed by President George Bush, it appeared to many people that the international security agenda was much more malleable and manageable than ever before. After all, since 1987, unprecedented progress had been made in (a) arms control, (b) overcoming East-West ideological divisions, (c) CSBMs, and (d) giving the UN a more active role. The world, it seemed, was ripe for strategic reform.

Michael Cox, 'Whatever Happened to the "Second" Cold War? SovietAmerican relations: 19801988', Review of International Studies, 16 (1990), pp. 155172.

47 See, for example, Booth (ed.), New Thinking About Strategy And International Security. It should also be noted that many observers believed that common security concepts could have an especially important role in the ending of the Cold War. See Ken Booth, 'Steps Towards Stable Peace in Europe'.

48 See Robert O’Neill, 'European Security in the 1990s: A New Organisation for a New ChallengeThe Alliance for Development in Europe', Australian Journal of International Affairs, 44:3 (December 1990), pp. 211220.

$49 \quad$ Palme Commission, p. 164; more generally, see pp. 161467. 


\section{Cooperative security}

In the post-Cold War climate a relatively new term became current in the debate on international relations, cooperative security; this term attempted to see beyond the narrow defence planning aspects of security while avoiding the loss of analytical focus which threatened the debate. The new formulation seemed to be a more useful, or perhaps more comfortable, term for officials. The term did not normally carry the more radical baggage sometimes closely associated with common security, such as anti-nuclearism, nor did it emphasise non-offensive defence. ${ }^{50}$

Instead, cooperative security tended to stress a re-tooled idea of nonprovocative defence: NPD was seen by many as a more permissive and less radical notion than NOD. ${ }^{51}$ In addition, there was considerable interest in exploring pragmatic efforts to build on common strategic interests. In practice, this pragmatism usually pointed towards incrementalism within an evolving framework of bilateralism and regional multilateralism. Both of these approaches were more often than not anchored on Washington. A major aim was the orderly management of the ending of the Cold War. Here the effort to operationalise cooperative security relations between Washington and Moscow, particularly with regard to nuclear issues, stands out. This was associated with, and followed by, efforts to establish a stable strategic framework for the post-Cold War order.

Running parallel with these efforts (and in some cases overlapping them) was an emerging debate on security concepts in the Asia-Pacific region. Again, the focus was often on preventing the destabilisation of international order which might occur as a result of the changing balance of power. A particular objective was to keep the US engaged in the region and, failing this, provide insurance in the event of an American retreat. The result was a mix of various Western and indigenous ideas (some of which had a relatively long pedigree). The picture was quite complex, a fact reflected in disagreement about whether the region was conducive to, or ready for, new approaches. ${ }^{52}$ Often the security dimension of the issue was intimately associated with broader areas of international relations. These included debate over the most appropriate paths to economic development, the issue of regional identity,

50 But, for a relatively radical exposition of cooperative security which shared a good deal with earlier discussions on common security, see Randall Forsberg, 'Creating a Cooperative Security System', in Forsberg et al., 'After the Cold War: A Debate on Cooperative Security', Boston Review, 17:6 (1992).

51 See Butfoy, Critical Reflections on Non-Offensive Defence, especially the appendix.

52 This debate occurred within the context of different perceptions of the dominant forces at work in the region and the consequent prospects for peace. For example, see, Barry Buzan and Gerald Segal, 'Rethinking East Asian Security', Survival (Summer 1994), pp.321; James Richardson, 'AsiaPacific: The Case for Geopolitical Optimism', National Interest, 38 (Winter 1994/95), pp.2839; and the related correspondence in Survival, 37:1 (Spring 1995), pp. 184187. 
1994), pp. 3751.

56 Like its relatives, the term cooperative security has been used in diverse and contradictory ways; on this point refer to note two. My bench mark for the following discussion is three major contributions to the literature: Dewitt, 'Common, Comprehensive, and Cooperative Security'; Nolan (ed.), Global Engagement; and Gareth 
20. For an attempt to 'bring in' common security thinking into the debate on cooperative security in the AsiaPacific region, see Mack and Kerr, 'The Evolving Security Discourse in the AsiaPacific'. For an earlier and more conservative definition of cooperative security in its European context, see, Windass and Grove, The Crucible of Peace, pp. 1011.

Nolan (ed.), Global Engagement, p. 5.

Evans, Cooperating for Peace, p. 16. Evans also includes the notion of 'comprehensive security' within his idea of cooperative security. For a sketch of some of the differences and overlap between these various concepts, see Andrew Mack, Concepts of Security in the Post-Cold War (Canberra: ANU Department of International Relations, Working Paper 1993/8). Note that this paper also seems to offer clues as to the derivation of some of Evans's ideas (compare, for example, p. 15 with the quote given below).

Evans, Cooperating for Peace, p. 16; In addition, see Dewitt, 'Common, Comprehensive, and Cooperative Security', especially pp. 78. 
possible responses to security problems through which the international community is now struggling to find a way'. ${ }^{60}$ Of course, if this is true the concept may well be almost vacuous.

\section{Seeing through the conceptual fog}

The fuzziness that frequently surrounds discussions on common/cooperative security arises because many of the critiques of Realism (a critique which, as discussed above, provides part of the basis for 'new' or 'alternative' schools) have been somewhat over-drawn and cliched. Also, in contrast to what some people have implied, most governments-especially in the West-have not, in practice, dogmatically followed 'the Realist line' as it is portrayed by common security polemicists. By and large Western governments especially, and many others in general, have for decades been quite aware that the world is complex, interdependent and demands (as well as offers opportunities for) cooperation. Contrary to what an unwary student might think after reading some of the literature on common security, multilateralism thrived during most of the Cold War years.

Refinements of the concept of common security seem to owe a considerable intellectual debt to pre-existing and well established notions of international relations. Of particular note here are the Neo-Liberal and International Society schools. Here the emphasis is on looking beyond the anarchical international system and towards the potential for deepening an anarchical international society. ${ }^{61}$

Within this setting, Neo-Liberalism places a strong emphasis on exploring the politics of interdependence in a context of anarchy. ${ }^{62}$ Here international relations is viewed, at least in part, as a process in which learning is possible. This is manifested in the emphasis on absolute gains, the development of both international organisations (such as the UN) and 'international regimes'. International regimes (which will be discussed at greater length below) are sets of rules, norms and expectations which surround particular issue areas (such as trade and nuclear non-proliferation). These regimes provide states with a means of dealing with some of the problems thrown up by complex patterns of interdependence.

60 Evans, Cooperating for Peace, p. 16.

61 For a discussion of the relationship between society and system in this context, see Barry Buzan, 'From International System to International Society: Structural Realism and Regime Theory Meet the English School', International Organization, 47:3 (Summer 1993), pp. 327352.

62 See, for example, Robert Keohane and Joseph Nye, Power and Interdependence: World Politics in Transition (Boston: Little, Brown and Company, 1977). 
Within the International Society school ${ }^{63}$ the notion of international institution tends to be understood more broadly than in Neo-Liberalism; it certainly goes further than international organisations, and it readily encompasses, for example, the customs adopted by international society (including war, as well as diplomacy, etc.). This branch of international relations theory focuses on, among other things, the historical origins and evolution of the normative dimensions of international relations, especially as they relate to questions of international order; a particular focus has been on the development of the balance of power, diplomacy and the philosophical bases of international law.

Both Neo-Liberalism and the International Society school can be seen as efforts to overlay Realist perspectives with more subtle insights and more explicit normative positions. They are both open to the possibility of significant change within the international system. However, they each dwell on different logics at work in international relations. ${ }^{64}$ Neo-liberalism identifies a series of 'functional' logics. The emphasis is on the further development of regimes based on calculations of states' interests in particular, relatively narrow, issue areas. Here the time scale for significant change can, in some cases, be quite short (from a few to several years). The International Society school stresses 'civilisational' logic; here the concern is with somewhat broader and more subjective matters-such as beliefs about what ought to be required and delivered in international society, especially in terms of moral conduct, mutual recognition and political responsibilities. For these sorts of issues significant change might take decades, even centuries, to occur. ${ }^{65}$

\section{Three variants of common security?}

For the purposes of this examination three variants of common security will be outlined in an effort to add some additional conceptual clarity and analytical depth to the discussion. These variants are: utopian, 'Palme-SIPRI', and institutionalist. These categories are, of course, abstractions. It would be difficult to unequivocally fit each and every official and academic statement on common security into one or other of these boxes. This is partly because few authors of such statements are particularly self-conscious about the intellectual pedigree or theoretical context of their ideas. More particularly, most discussions on international security rest on a

63 For a seminal text, see Hedley Bull, The Anarchical Society: A Study of Order in World Politics (London: Macmillan, 1977).

64 For discussions of the relationship between these two branches of international relations scholarship, see, Tony Evans and Peter Wilson, 'Regime Theory and the Millennium, 21:3 (1992), pp. 329351; and Buzan, 'From International System to International Society'.

65 The terms functional and civilisational logic are from Buzan, 'From International System to International Society'. As Buzan notes, the working-out of such logics is likely to be uneven both over time and geographically. 
blend of different, often unconsciously held, assumptions. Having made this necessary qualification, the three variants may be summarised as follows:

- Utopian approaches to common security are essentially contemporary equivalents of the old Liberal Internationalist and World Society schools of international relations. Here it is assumed that peace can follow disarmament, international law and a recognition of our common humanity.

- The 'Palme-SIPRI' approach ${ }^{66}$ is the closest of the variants under discussion to the normative and analytical roots of common security thinking as it developed in the 1980s. Nearly all the significant early writings on common security (such as the Palme Commission) made a conscious effort to avoid the naivety which flawed idealist prescriptions in the 1920s and 1930s. However, as discussed above, few of these efforts managed to completely succeed in shaking off this part of their heritage. Nevertheless, there was usually a serious engagement with practical issues. Here it is worth noting Barry Buzan's observation which locates common security in the 'synthesis between the logic of anarchy and the imperatives of Idealism'. He saw common security thinking as going some way in laying the 'foundations...for a convergence in the Realist and Idealist agendas'. ${ }^{67}$

- The institutionalist variant of common security can be closely associated with the picture of cooperative security sketched earlier. To reiterate: the emphasis here is on cooperative, multilateral diplomacy (including international organisations). In practice, these efforts are often aimed at institutionalising key aspects of the status quo. ${ }^{68}$ Potentially, at least, this variant can itself be divided into at least three overlapping sub-categories: (a) one directly reflecting Neo-Liberal sources; (b) one more closely resembling International Society perspectives; and (c) one which owes its intellectual heritage to a more even mix of the two schools.

These abstractions are not offered in order to place specific authors or policies into mutually exclusive intellectual straight-jackets. Rather, the aim is to illustrate the sort of spectrum of opinion and concepts upon which the common security debate rests. ${ }^{69}$

66 This label is simply one of convenience; not too much should be read into it. I am certainly not suggesting that every one who worked at SIPRI during the 1980s blindly accepted the same blueprint for common security. Nevertheless, many SIPRI publications of the time did seem to have a relatively distinct flavour.

67 See Buzan, People, States and Fear, p.13.

68 One must be careful not to exaggerate the place of formal institutions in some of the literature on cooperative security. Dewitt, for example, goes out of his way to state that: 'Institutionalisation is a secondary and derivative issue...'. See 'Common, Comprehensive, and Cooperative Security', p. 11. I am using the word institution in a broad sense to include, for example, patterns of bilateral and multilateral diplomacy, collective security, and formal arms control.

69 If one wanted to stretch this theme even further one could point to the fact that the rhetoric of common security can be used by governments to describe little more than 


\section{Security regimes}

Both the functional and civilisational logics which shape international society obviously have enormous significance for the debate on international security. In practice they both point to the desirability of the further evolution of particular types of international security regimes. Robert Jervis refers to these regimes as:

...those principles, rules, and norms that permit nations to be restrained in their behavior in the belief that others will reciprocate. This concept implies not only norms and expectations that facilitate cooperation, but a form of cooperation that is more than the following of short-run selfinterest. 70

Similarly, Evans identifies security regimes as:

...international laws, norms, agreements and arrangements-global, regional and bilateral in scope-designed to minimise threats to security, promote confidence and trust, and create institutional frameworks for dialogue and cooperation 71

An important rationale for the development of security regimes is the fostering of 'strategic reassurance'. Carefully crafted regimes have the potential to make governments relatively relaxed about engaging in cooperative ventures. Such regimes reduce the risk that cooperation will expose a state to predatory behaviour. As Antonia and Abram Chayes have noted, reassurance has replaced deterrence as 'the central strategic problem for a cooperative security regime'. ${ }^{72}$

Most international security regimes can be discussed in terms of four, frequently overlapping, categories. ${ }^{73}$ First, there are legal regimes covering, for example, maritime issues and the Geneva Conventions. Second, there are dialogue regimes intended to precipitate and encourage habits of cooperative behaviour, often on a regional basis (such as in the case of CSCE and ASEAN). Third, there are arms control regimes. Fourth, it may be possible to develop defence planning regimes whereby governments would be restrained in their formulation of national military strategies and encouraged in their commitment to both NPD and collective security.

There are constraints on how far the logic of security regimes can be pushed. There are four overlapping reasons for this, each of which have important impli-

limited cooperation for quite narrow short-term interests; in this instance the language of common security becomes compatible with Realist thinking.

70 Robert Jervis, 'Security Regimes', International Organizations, 36:2 (1982), p. 357.

71 Evans, Cooperating for Peace, p. 40.

72 Antonia and Abram Chayes, 'Regime Architecture: Elements and Principles', in Nolan (ed.), Global Engagement, p. 65.

73 This list is an extension of the ideas offered in Evans, see Cooperating for Peace, p. 40. 
cations for the limits of strategic reform. First, as Jervis has noted, 'the security area is unforgiving. Small errors can have big consequences'. ${ }^{74}$ This puts a premium on caution and incrementalism. Second, calls for restraint sometimes ring hollow in a hostile political environment; such calls may seem academically attractive but, to those with the responsibility for making life and death decisions (the Israeli cabinet, for example), somewhat naive. Third, some states deliberately set out to create insecurity for others. World politics is not populated entirely by nice liberals, and war is not always the result of misunderstanding. Fourth, some security regimes may well be inimical to broadly cooperative or common approaches to security. Indeed, at times regimes may have much more to do with reinforcing selfish and/or hegemonic interests.

\section{Recasting common security}

The meaning of common security needs to be recast if it is to have much distinctive analytical or prescriptive weight. It needs rescuing from the confusing proliferation of terms and meanings which mark 'new' approaches to security. It is tempting here to let go of the term and invent a new one for what I want to say, but this may only add to the problem. In any case, among other things, I want to illuminate the ways that contemporary notions of common/cooperative security can be evaluated in terms of some of the ideas, even ideals, which motivated much of the early thinking on the subject. Abandoning the field (and the labels) to the 'opposition' may not be the best way to do this.

On the other hand, though, some of the early thinking on common security was seriously flawed, especially with regard to the tendency to side-step the contradictions and complexities of international life and thereby slide towards Utopianism. However, to gut common security of its moral message (i.e., that the security of more and more people should be enhanced) is to reduce the term to mean little more than progressive diplomacy and the techniques of regime management. While neither of these things are to be sneered at, the task set here is to restate the deeper moral message while remaining relevant to 'practical' matters.

The concept of common security should not be considered in isolation from political and strategic practice. If there is a mismatch between concepts of common security and the workings of the international system, then so much the worse for theory. This does not mean that difficult to achieve ethical goals, or radical strategic prescriptions, have to be abandoned. But it does mean that these goals and prescriptions ought to be grounded, at least to a degree, in political and strategic practice. Common security ought to be about the development of practical measures which make it possible to approximate idealistic aims. This suggests, but does not 
dictate, that schemes for common security have to tread a fine line between conservatism and radicalism.

This section outlines a conceptual framework for a revised form of common security. What follows is not a theory of international security, nor is it a prediction of how things will be. Rather, it is a set of connected reference points for evaluating and framing strategic reform. These reference points suggest how interdependence and the evolution of international society are modifying the ways we ought to assess and steer strategic planning. The aim is to suggest ways in which particular ideas and policies might take us towards a less militarised and safer (but not necessarily safe) international system.

The approach adopted here is relatively open. For example, it calls for the inclusion of an ethic of the 'common good', but it does not detail what the substance of such an ethic should be. No attempt to 'lay down the law' is attempted here because I am more concerned with suggesting generalised criteria for framing strategic reform than with explaining the nature of world politics (although these two activities cannot be completely divorced). This approach to common security is constructed around the following seven connected conceptual and normative propositions: 75

(i) States should be seen-and ought to act-as institutional components of, and moral agents within, a possible world society. Without an ethic of responsibility for global welfare, common security thinking would become little more than a sterile exercise in the management of the strategic mechanics of interdependence. Common security should be more than a call for a collection of issue-specific regimes. It should also be about setting these regimes into a broader context which emphasises the potential evolution of political communities (or at least identities) beyond the state. Common security also requires that a critical mass of states accept the notion of 'good international citizenship' and a related responsibility to (in Hedley Bull's words) 'act as local

76 In a way, the advancement of common security can be viewed as the security dimension of good international citizenship. At the level of strategic policy (as opposed to the human rights, economic, and environmental policy levels), this points towards measured approaches to NPD/NOD and the use of arms control as a stepping stone towards very significant levels of disarmament. It also suggests qualified support for collective enforcement measures. More generally, the placing of

75 It should be clear that the following framework cannot be defended as objectively true. The construction is both explicitly prescriptive and essentially subjective. It also leaves enormous scope for argument and debate within the suggested framework.

76 See Hedley Bull, 1983-84 Hagey Lectures (Waterloo, University of Waterloo, 1985), p.14, and Andrew Linklater, 'What is a Good International Citizen?' in Paul Keal (ed.) Ethics and Foreign Policy (St. Leonards, NSW: Allen and Unwin, 1992). 
notions of world society on the foreign policy agenda could be expected to further open up that area to moral argument. ${ }^{77}$

(ii) The interplay between (a) anarchy at the international level, (b) interdependence, and (c) political culture, provides a key reference point for security planning. Each of these factors places heavy constraints on how defence planning is conceived and implemented. This means, by extension, that these factors also place limits on the progress that can be expected in advancing common security. The security environment for many states is still overshadowed by the fact that the international system is essentially anarchic (i.e., lacking some kind of world government). This, in turn, convinces many governments that security largely turns on 'self-help'. This can reinforce the general danger of international life as the international system becomes viewed by some governments as a struggle for power. On the other hand, however, states are not inevitably trapped in a one-dimensional world of power politics. At the end of the twentieth century networks of interdependence and transnational activity, as well as evolving notions of international society and the evolution of domestic political cultures, are often as much a part of the framework in which security policy has to be developed as are claims to sovereignty within an anarchic international setting. Robert Keohane has noted that the fact of anarchy 'cannot explain variation in patterns of conflict and cooperation among states'. ${ }^{78}$ In other words, there are additional factors at work. As Alexander Wendt has said, 'anarchy is what 79 This is one reason why the evolution of selected

77 However, the precise boundaries of this world society, and the precise relationship it has to traditional ideas of international society, are matters of considerable debate. For example, the sentiments expressed here mesh into the idea that the central reference point for debate on security should shift from states to people. As Evans and others have pointed out, many of the major security problems in the contemporary world concern the plight of individuals caught up in intrastate conflict. See Evans, 'Cooperative Security and Intrastate Conflict'. An obvious and important cautionary point needs to be made here. By placing people (rather than states) at the centre of the debate on global security some very awkward questions surface regarding intervention in the internal affairs of sovereign states. For example, who should decide what type and degree of human suffering within a state is intolerable? To what extent should abuses of human rights be allowed to licence or justify intervention by the great powers or the UN? To what extent will concerns for intrastate security jeopardise interstate security? For a theoretical discussion of 'referent objects' in security analysis, see Buzan, People, States and Fear. The issue overlaps with the debate on collective security; see Andrew Butfoy, 'Themes Within the Collective Security Idea', Journal of Strategic Studies, 16:4 (December 1993), pp. 490510.

78 Keohane, 'Institutional Theory and the Realist Challenge after the Cold War', p.287.

79 See Wendt, 'Anarchy is What States Make of it'. In addition, see, Buzan, People, States and Fear, pp. 178181; John Keegan, A History of Warfare; John Mueller, Retreat from Doomsday: The Obsolescence of Major War (New York: Basic Books, 1989).

For a debate on the possibility of learning in international security relations, see Carl Kaysen, 'Is War Obsolete? A Review Essay', John Mearsheimer, 'Back to the Future: Instability in Europe After the Cold War', and Stephen Van Evera, 'Primed for Peace: 
international regimes will probably be central to the further development of common security.

(iii) We need an understanding of international relations which draws on the insights of a range of theories of international relations. For example, Realist, International Society and Neo-Liberal perspectives each have something valuable to say about international relations. Each, in its own way, illuminates different aspects of contemporary international life. The theoretical basis of the normative argument presented here rests largely on a synthesis of the Neo-Liberal and International Society schools. ${ }^{80}$ For example, it is assumed that international society can and ought to be (but not necessarily will be) deepened through the working out of both the functional and civilisational logics described earlier.

(iv) Cooperative approaches to national security planning will often be more appropriate and efficacious than competitive strategies. Given the above three propositions, and given also that security has to be achieved within a perhaps increasingly interdependent international system, the incentives for (and probably the scope for) cooperative approaches may well expand in the future. In addition, it seems likely that, for much of the world at least, interdependence could help change or mould notions of ethics, identity and interest. Some of these changes might reflect a growing sense of regional identity and global community. If this were to occur to any significant degree, it is only natural that, in time, it will impact on strategic planning.

(v) For cooperative approaches to security to gather political momentum, the concept of strategic reassurance needs to be given greater salience. Strategic reassurance is about providing states with the confidence that their security will not be undermined by cooperation. In most cases this would probably require neighbours to make clear commitments to cooperative security regimes. States need to know that cooperation will not jeopardise their security: cooperation should not leave them vulnerable to long-standing or emerging threats.

(vi) The region should be seen as a focal point in the effort to translate the concept of common security into policy. Although many issues (such as nuclear proliferation) need to be dealt with on a global level, most of the day-to-day problems with operationalising common security are likely to occur in fairly distinct regional contexts.

Europe After the Cold War', all in Sean Lynn-Jones and Steven Miller (eds), The Cold War and After: Prospects for Peace (Cambridge: MIT Press, 1993).

80 However, I am not convinced that we are particularly close to discovering the theory of international relations (if there is such a thing to be discovered). It is just that, in terms of this discussion, these two approaches suggest something interesting and illuminating about the workings of international society. In addition, it is recognised that, at times, (a) some governments will be very concerned about relative gains, and (b) domestic political factors can sometimes powerfully influence international developments. 
(vii) Common security concepts help to reframe conflict, they can not be relied upon to eliminate it. The language of common security should therefore not be used to wish away security problems. As Buzan has written:

...the practical meaning of security can only be constructed sensibly if it can be made operational within an environment in which competitive relations are inescapable. If security depends on either harmony or hegemony, then it cannot be lastingly achieved within anarchy. Among other things, this means that under anarchy, security can only be relative, never absolute. ${ }^{81}$

The obstacles to the full development of common security are considerable. They can be divided into six overlapping categories. First, the structural condition of anarchy is seen by many governments and analysts to impose a contrary (Realist) logic on international relations. 'Self-help' often takes precedence over notions of collective effort for the common good. This gives the very idea of common security rather shaky foundations. At a minimum the requirement is for 'a shared interest in survival'. A less minimalist approach would call for 'a shared concern for security'. The problem is that this shared concern is sometimes only skin deep. This is nowhere more apparent than in the practice of UN sanctioned collective security. It is clear that the world has not adopted the philosophy of 'all for one and one for all'. The exercise of collective security has been partial, discriminatory, and subject to double standards. Considerations of power, and the pursuit of non-common interests, have frequently dominated discussions of the issue. Second, the precise content of the common good is subject to intense controversy. This lack of agreement is both reflected in, and reinforced by, the keenness with which state sovereignty is held on to. Among other things, sovereignty is a form of self-defence against the danger that 'the common good' might be employed as a cover for various forms of quasi-colonialism. Third, there are enormous domestic political constraints on what can be achieved at the international level. It seems that most people are not deeply concerned about the insecurity of millions of fellow humans. This is bound to impose constraints on foreign and defence policy. Fourth, the world is, on one level at least, divided into the 'haves' and the 'have nots' in security as well as economic terms; moreover, it is the haves that seem to be setting the new 'common' security agenda. While, at times, this agenda does reach out to the global periphery, this is usually because things have become a nuisance, or an embarrassment, to the centre. Fifth, there is only so much that the international community can do to create a safe world for people caught up in insecure political conditions. Ultimately, the level of security that prevails is a product of both structural factors (such as arms racing and the international economic system) and political culture. The real requirement is for 
This expression is from Booth, 'Steps Towards Stable Peace in Europe', p. 32. 
(iv) effective fall-back provisions for sanctions in the event of recalcitrant states intent on violating the provisions of widely accepted norms; and, related to this point, a system of collective security;

(v) deterrence, which could be underpinned, primarily, by the achievement of (i) and (iv) above.

However, as already indicated, such measures can only get us so far. The best way to lessen the chances of war and promote significant levels of demilitarisation is to encourage pacific political cultures and to further delegitimise the idea that armed force is an acceptable or sensible way of conducting business on the international stage. Here foreign policy is likely to have a greater role than defence planning. As suggested above, the role of strategic reform in the promotion of common security is secondary to political and cultural factors. These non-military phenomena seem to shape military matters much more than they are shaped by them. However, although strategic reform is likely to remain secondary, it may nonetheless have a significant role to play in enhancing political relations. This role has three aspects to it: reducing the conflict exacerbating effects of worst-case analysis; improving the prospects for collective security; and increasing strategic reassurance. Insofar as these objectives can be met, they could reasonably be expected to widen and deepen the political constituency for common security.

\section{Conclusion}

The further development of common security, insofar as it occurs at all, will rest on a series of compromises between more or less radical aspirations and conservative concerns. In practice this means that considerations of the balance of power (however ill-defined the concept is in the literature) and, more particularly, the interests of the powerful, will exert a strong influence over the debate. This has both negative and positive aspects. On the positive side, it may well be that some powerful actors can continue to be convinced of the merits of particular aspects of the common security agenda. Among other things, this could facilitate the further development of cooperative approaches to security issues. More negatively, there is considerable scope for the agenda to be further reconstructed around the interests of the most powerful, most privileged and most secure members of international society. There will be times when this reconstruction conflicts with the interests of the least powerful, least privileged, and least secure members of this society.

Since the mid-1980s the constituency for common security has grown enormously and, despite the many conflicts which mar contemporary international relations, the prospects for the further deepening and broadening of this constituency appear quite bright. A large caveat has to be made here, however. The term common security (and cooperative security) is so elastic and has been employed so loosely that it lacks any exact, universally accepted meaning. Common 
security has become a catch-all phrase; it is often more of a slogan than a well defined political program. Most governments, it seems, pay at least lip-service to the idea (even though the content of their policies often appears to bear a striking resemblance to traditional ways of doing business). What we are left with, it often seems, is a collection of terms with overlapping meanings. More often than not these meanings are not especially profound. They suggest that often states will have security concerns in common which should be tackled in a cooperative fashion. In this way the jargon of common/cooperative security is frequently employed as little more than a call for sensible diplomacy-and sometimes as little more than rhetorical cover for what is really discriminatory security.

Nevertheless, despite all of the reservations made in this paper, the concept of common security can be recast to provide useful signposts to academics and decision-makers interested in exploring the prospects for a safer world. Given appropriate qualification, the idea suggests a framework which brings together a recognition of some of the practical problems associated with defence planning, and a sense of the sort of conceptual and ethical considerations which can be valuable in steering policy debate. 


\section{DEPARTMENT OF INTERNATIONAL RELATIONS PUBLICATIONS as at 1 September 1995}

\section{WORKIng PAPers:}

Send all orders to:

Publications Officer

Department of International Relations

Research School of Pacific and Asian Studies

The Australian National University

Canberra ACT 0200 Australia

Phone: (06) 249 4451/279 8089 Fax: (06) 2798010

WP1989/1 The Changing Central Balance and Australian Policy, by Coral Bell

WP1989/2 Agricultural Trade and Australian Foreign Policy in the 1990s, by Stuart Harris

WP1989/3 The Politics of Reassurance: Egypt and the Arab World, 1977-1987, by Ralph King

WP1989/4 Analysing the Impact of International Sanctions on China, by Peter Van Ness

WP1989/5 Economic Change in the International System Implications for Australia's Prospects, by Stuart Harris

WP1990/1 Middle Power Leadership and Coalition Building: The Cairns Croup and the Uruguay Round,

by Andrew Fenton Cooper and Richard A. Higgott

WP1990/2 The Soviet Far East, by Geoff Jukes

WP1990/3 The Environmental Challenge: The New International Agenda, by Stuart Harris

WP1990/4 India in Southwest Asia, by Amin Saikal

WP1990/5 Is Unilateral Trade Liberalisation the Answer? by Trevor Matthews and John Ravenhill

WP1990/6 The Politics of Baltic Nationalisms, by William Maley

WP1990/7 Peacekeeping in the South Pacific: Some Questions for Prior Consideration, by Greg Fry

WP1990/8 Informal Theories of Rationality, by James L. Richardson

WP1990/9 The Limits to Liberalisation in Industrialising Asia: Three Views of the State, by James Cotton

WP1990/10 The Influence of the United Nations on the Antarctic System: a Source of Erosion or Cohesion? by Stuart Harris

WP1991/1 International Trade, Ecologically Sustainable Development and the GATT, by Stuart Harris

WP1991/2 Middle Powers and International Sanctions: Generic Theory Reconsidered, by Kim Richard Nossal

WP1991/3 Continuity and Change in Cooperative International Regimes: The Politics of the Recent Environment Debate in

Antarctica, by Lorraine M. Elliott

WP1991/4 Foreign Policy Analysis, International Relations Theory, and Social Theory: Critique and Reconstruction, by Ian Bell

WP1991/5 China as a Third World State: Foreign Policy and Official National Identity, by Peter Van Ness

WP1991/6 The Drawbacks of the Detached View: Russia, the USSR and the Pacific, by Artem Rudnitskiy

WP1991/7 'Civil Society' and Nationalism in North Korea: Foundations for Political Change? by James Cotton

WP1991/8 Australia and the South Pacific: From 'Strategic Denial' to 'Constructive Commitment', by Greg Fry

WP1991/9 Implementing Foreign Policy: The Environmental Challenge, by Stuart Harris

WP1991/10 The Korean Nuclear Issue, by Song Young Sun

WP1992/1

WP1992/2

WP1992/3

WP1992/4

WP1992/5

WP1992/6

WP1992/7

WP1992/8

WP1992/9

WP1992/10

WP1993/1

WP1993/2

WP1993/3

WP1993/4

WP1993/5

WP1993/6

WP1993/7

WP1993/8

WP1993/9

WP1993/10

WP1994/1

WP1994/2

WP1994/3

WP1994/4

WP1994/5 WP1994/6

After the Cold War and the Gulf War: Prospects for Security in the Asia-Pacific, by Andrew Mack

Questions About a Post-Cold War International Order, by J.L. Richardson

New Hierarchies in East Asia: The Post-Plaza Division of Labour, by Mitchell Bernard and John Ravenhill

Federalism and Australian Foreign Policy, by Stuart Harris

Moving Target-Korea's Nuclear Proliferation Potential, by Peter Hayes

The Economic Aspects of Pacific Security, by Stuart Harris

The Gulf War and Australian Political Culture, by James L. Richardson

The Case For a Nuclear Weapon-Free Zone in Northeast Asia, by Andrew Mack

Nuclear Dilemmas: Korean Security in the 1990s, by Andrew Mack

Arms Proliferation in the Asia-Pacific: Causes and Prospects for Control, by Andrew Mack

The Practice of Common Security: China's Borders with Russia and India, by Gary Klintworth

Strategic Trade Policy: The East Asian Experience, by Trevor Matthews and John Ravenhill

Environmental Regulation, Economic Growth and International Competitiveness, by Stuart Harris

The Environment and Sustainable Development: An Australian Social Science Perspective, by Stuart Harris

Gaddis' Lacuna: Foreign Policy Analysis and the End of the Cold War, byValerie Hudson

The Return of Practical Reason, by Hayward R. Alker, Jr.

An American New World Order?, by James L. Richardson

Concepts of Security in the Post-Cold War, by Andrew Mack

Australian Security in the 1990s, by Andrew Mack

Nuclear-Free Zones in the 1990s, by Andrew Mack

Inter-Civilisation Conflict: A Critique of the Huntington Thesis, by Jacinta O'Hagan

The Future of Asia-Pacific Security Studies in Australia, by Pauline Kerr and Andrew Mack

Australia's Regional Security Environment, by Stuart Harris

Policy Networks and Economic Cooperation: Policy Coordination in the Asia-Pacific Region,

by Stuart Harris

North Korea's Nuclear Program: the Options are Shrinking, by Andrew Mack

The Asia-Pacific: Geopolitical Cauldron or Regional Community?, by James L. Richardson 
WP1994/7 'Climbing Back onto the Map?': The South Pacific Forum and the New Development Orthodoxy, by Greg Fry

WP1994/8 Human Rights and Cultural Specificity: The Case of Papua New Guinea, by Michael Jacobsen

WP1994/9 Nuclear Endgame on the Korean Peninsula, by Andrew Mack

WP1994/10 China's Public Order Crisis and Its Strategic Implications, by Greg Austin

WP1995/1 New Light on the Russo-Japanese Territorial Dispute, by Kimie Hara

WP1995/2 Implications of Taiwan-Chinese Relations for Australia, by Stuart Harris

WP1995/3 In Search of a New Identity: Revival of Traditional Politics and Modernisation in

Post-Kim Il Sung North Korea, by Alexandre Y. Mansourov

WP1995/4 The Neo-Classical Ascendancy: The Australian Economic Policy Community and Northeast Asian Economic Growth, by Trevor Matthews and John Ravenhill

WP1995/5 The World Trade Organisation-Throwing the Baby Out With the Bath Water? by P.A. Gordon

WP1995/6 Culture, Relativism and Democracy: Political Myths About 'Asia' and the 'West' by Stephanie Lawson

WP1995/7 Russian Policy Towards the 'Near Abroad': The Discourse of Hierarchy by Wynne Russell

WP1995/8 Recasting Common Security, by Andy Butfoy

Price: All at the one price of \$A5.

\section{Canberra Studies in World Affairs:}

Send all orders to:

Reply paid 440, Bibliotech

ANUTECH

Canberra ACT 0200 Australia

Telephone: (616/06) $2493811 / 5662$

Fax Order: IDD (616) STD (06) 2571433

CS21 Politics, Diplomacy and Islam: Four Case Studies, edited by Coral Bell $\$ 10.00$

$\begin{array}{ll}\text { CS22 The Changing Pacific: Four Case Studies, edited by Coral Bell } & \$ 10.00\end{array}$

CS23 New Directions in International Relations? Australian Perspectives, edited by Richard Higgott $\$ 10.00$

CS24 Australia and the Multinationals: A Study of Power and Bargaining in the 1980s, by Neil Renwick $\$ 10.00$

$\begin{array}{ll}\text { CS25 Refugees in the Modern World, edited by Amin Saikal } & \$ 10.00\end{array}$

CS27 Northeast Asian Challenge: Debating the Garnaut Report, edited by J.L. Richardson $\$ 15.00$

CS28 The ANZUS Documents, edited by Alan Burnett with Thomas-Durell Young and Christine Wilson $\$ 15.00$

$\begin{array}{ll}\text { CS29 Human Rights in the Asia-Pacific Region, edited by John Girling } & \$ 15.00\end{array}$

CS30 International Relations: Global and Australian Perspectives on an Evolving Discipline, edited by Richard Higgott and J.L. Richardson

\section{STUdiEs In WORLD AFFAIRS:}

Send all orders to:

Allen \& Unwin Pty Ltd

9 Atchison Street

St Leonards NSW 2605 Australia

Ph: (02) 901 4088, Fax: (02) 9062218

Ethics and Foreign Policy, edited by Paul Keal

Korea Under Roh Tae-woo: Democratisation, Northern Policy, and Inter-Korean Relations,

edited by James Cotton

Asian-Pacific Security After the Cold War, edited by T.B. Millar and James Walter

The Post-Cold War Order: Diagnoses and Prognoses, edited by Richard Leaver and James L. Richardson \$24.95

Dependent Ally: A Study in Australian Foreign Policy, 3rd ed., by Coral Bell

A Peaceful Ocean? Maritime Security in the Pacific in the Post-Cold War Era, edited by Andrew Mack \$24.95

Asian Flashpoint: Security and the Korean Peninsula, edited by Andrew Mack $\$ 24.95$

$\begin{array}{ll}\text { Taiwan in the Asia-Pacific in the 1990s, edited by Gary Klintworth } & \$ 24.95\end{array}$

Pacific Cooperation: Building Economic and Security Regimes in the Asia-Pacific,
edited by Andrew Mack and John Ravenhill

The Gulf War: Critical Perspectives, edited by Michael McKinley $\$ 24.95$

Search for Security: The Political Economy of Australia's Postwar Foreign and Defence Policy, by David Lee $\$ 24.95$ 


\section{Australian Foreign Policy Papers}

Australian Foreign Policy Papers are published by the Australian Foreign Policy Publications Programme in the Department of International Relations:

Send all orders to:

Reply paid 440, Bibliotech

ANUTECH

Canberra ACT 0200 Australia

Telephone: (616/06) $2493811 / 5662$

Fax Order: IDD (616) STD (06) 2571433

Australia's Alliance Options: Prospect and Retrospect in a World of Change, by Coral Bell

Coping With Washington: Players, Conventions and Strategies, by Davis Bobrow

The European Community in Context, by John Groom

$\$ 15.00$

Australia's Human Rights Diplomacy, by Ian Russell, Peter Van Ness and Beng-Huat Chua

$\$ 15.00$

Selling Mirages: The Politics of Arms Trading, by Graeme Cheeseman

$\$ 15.00$

The Search for Substance: Australia-India Relations into the Nineties and Beyond,

by Sandy Gordon

$\$ 15.00$

Protecting the Antarctic Environment: Australia and the Minerals Convention,

by Lorraine Elliott

Australia's Taiwan Policy 1942-1992, by Gary Klintworth

Australia and the New World Order: Evatt in San Francisco, 1945, by W.J. Hudson

The Beijing Massacre: Australian Responses, by Kim Richard Nossal

The Pacific Patrol Boat Project: A Case Study of Australian Defence Cooperation,

by Anthony Bergin

A Select Bibliography of Australia's Foreign Relations, 1975-1992, compiled by Pauline Kerr

David Sullivan and Robin Ward

Australia's Evolving American Relationship: Interests, Processes and Prospects for Australian

Influence, by Henry S. Albinski

* Plus $\$ 3.00$ postage and packaging per copy ordered. 




\title{
DEPARTMENT OF INTERNATIONAL RELATIONS
}

\author{
Publications Order Form
}

\section{WORKING PAPERS ONLY}

\section{Please Supply}

Copies of IR Working Paper No.

Copies of IR Working Paper No.

Copies of IR Working Paper No.

Copies of IR Working Paper No.

Copies of IR Working Paper No.
Copies of IR Working Paper No.

Copies of IR Working Paper No.

Copies of IR Working Paper No.

Copies of IR Working Paper No.

Copies of IR Working Paper No.

* All Working Papers are \$A5.

Method of Payment (please tick)

Money Order

Cheque (made payable to: The Australian National University)

Mastercard/Visa Card Number

Expiry Date Signature

For Overseas Orders: Payment by Mastercard/Visa or by Bank Draft in Australian Dollars only, payable to Australian National University.

Name/Organisation:

Postal Address:

Suburb: State: Postcode:

Signature: Date:

\section{Please forward completed form and payment to:}

Publications Officer

Department of International Relations

Research School of Pacific and Asian Studies

Australian National University

CANBERRA ACT 0200 AUSTRALIA

Phone: (06) 249 4451/279 8089, Fax: (06) 2798010

Email: robin.ward@coombs.anu.edu.au 
